\author{
Ye.A. Daineko ${ }^{1,2 *}$, M.T. Ipalakova1 ${ }^{1}$, N.T. Duzbaev ${ }^{1}$, \\ D.D. Tsoy ${ }^{1}$, A.M. Seytnur ${ }^{1}$, A.Ye. Mishina ${ }^{1}$, D.K. Zhenisov ${ }^{1}$ \\ ${ }^{1}$ International University of Information Technologies, Kazakhstan, Almaty \\ ${ }^{2}$ Institute of Applied Sciences and Information Technologies, Kazakhstan, Almaty, \\ *e-mail: y.daineko@edu.iitu.kz

\section{USING VR FOR THE VIRTUAL PHYSICS LABORATORY "DETERMINING THE MOMENT OF INERTIA FOR A BALL»}

The article discusses the use of virtual reality technology in education. The main goal of the study is to provide students with a convenient, useful and interesting source of knowledge for studying physics. The analysis of the use of various innovative developments in the field of education was conducted. It is shown that virtual reality is a promising tool for educational use, allowing you to create a safe, affordable and flexible environment for studying various processes. While working in virtual reality, a user receives all the necessary information in an unusual, but very visual form. In the article the authors present a software application using virtual reality technology for studying the moment of inertia of a ball. The application is made in the form of laboratory work with the possibility to conduct a virtual experiment. For clarity, the article provides screenshots of the application scenes; the application logic is given in the form of a UML activity diagram. The cross-platform Unity 3D was chosen as the development environment, which implements the principle of WORA (write once, run anywhere). Thanks to this principle, once written application can be built for personal computers, mobile devices, helmets of mixed reality and many other platforms. As a virtual reality device, the Leap Motion controller was used. The application functionality was written in the $\mathrm{C} \#$ programming language. Graphic models were created using Substance Painter. The developed application can be used by high school students of secondary and specialized schools, students of technical specialties of higher educational institutions, as well as any interested users.

Key words: physics, education, virtual reality, virtual laboratory, unity, C\#.

\author{
Е.А. Аайнеко ${ }^{1,2 *}$, М.Т. Ипалакова ${ }^{1}$, Н.Т. Аузбаев ${ }^{1}$, \\ А.А. Цой ${ }^{1}$, А.М. Сейтнур ${ }^{1}$, А.Е. Мишина ${ }^{1}$, А.К. Женисов ${ }^{1}$ \\ 'Международный университет информационных технологий, Казахстан, г.Амматы \\ ${ }^{2}$ Институт прикладных наук и информационных технологий, Казахстан, г.Амматы \\ *e-mail: y.daineko@edu.iitu.kz \\ Использование технологии виртуальной реальности А^я разработки \\ виртуальной физической маборатории «Изучение момента инерции шара»
}

В Аанной статье обсуждается использование технологии виртуальной реальности в образовании. Основная цель исследования - обеспечить студентов удобным, полезным и интересным источником знаний для изучения физики. Был проведен анализ использования различных инновационных разработок в сфере образования. Показано, что виртуальная реальность является перспективным средством Аля использования в образовательных целях, позволяющим создать безопасную, Аоступную и гибкую среду Аля изучения различных процессов. Во время работы в виртуальной реальности пользователь получает всю необходимую информацию в необычной, но очень наглядной форме. ЗАесь преАставлено программное приложение с использованием технологии виртуальной реальности Аля изучения момента инерции шара. Приложение выполнено в виде лабораторной работы с возможностью проведения виртуального эксперимента. А^я наглядности представлены скриншоты со сценами приложения, логика приложения приведена в виде UML диаграммы деятельности. В качестве платформы разработки была выбрана кроссплатформенная среда Unity 3D, которая осуществляет принцип работы WORA (writeonce, runanywhere). Благодаря этому принципу единожды написанное приложение может быть собрано Аля персональных компьютеров, мобильных устройств, шлемов смешанной реальности и многих других платформ. В качестве устройства виртуальной реальности использова^ся контрол^ер Авижения Leap Motion. Функционал приложения бы^ написан на языке программирования С\#. Графические модели были созданы с использованием 
Substance Painter. Разработанное приложение может быть использовано учениками старших классов средних и специализированных школ, студентами технических специальностей высших учебных заведений, а также мюбыми заинтересованными пользователями.

Ключевые слова: физика, образование, виртуальная реальность, виртуальная ^аборатория, Unity, C\#.

\author{
Е.А. Аайнеко $1,2 *$, М.Т. Ипалакова ${ }^{1}$, Н.Т. Аұзбаев ${ }^{1}$, \\ А.А. Цой ${ }^{1}$, А.М. Сейтнұр ${ }^{1}$, А.Е. Мишина ${ }^{1}$, А.Қ. Жеңісов ${ }^{1}$ \\ ${ }^{1}$ Халықаралық ақпараттық технологиялар университеті, Қазақстан, Амматы қ. \\ ${ }^{2}$ Қолданбалы ғылымдар және ақпараттық технологиялар институты, Қазақстан, Алматы қ., \\ *e-mail: yevgeniyadaineko@gmail.com \\ «Аоптың инерция моментін анықтау» виртуалды физикалық зертханасын \\ құру үшін виртуалды шындық технологиясын пайдалану
}

\begin{abstract}
Мақалада білім берудегі виртуалды шындық технологиясын қолдану қарастырылады. Зерттеудің негізгі мақсаты студенттерді физика пәнін оқып үйренуге ыңғайлы, пайдалы және қызықты ресурстармен қамтамасыз ету. Білім беру саласында әртүрлі инновациялық әзірлемелерді пайдалануға талдау жүргізілді. Виртуалды шындық әр түрлі үАерістерді зерттеу үшін қауіпсіз, қолжетімді және икемАі ортаны құруға мүмкіндік беретін білім беру мақсаттарында қолдану үшін перспективалы құрал болып табылады. Виртуалды шындық кезінде пайдаяанушы барлық қажетті ақпаратты ерекше, бірақ өте көрнекі түрде алады. Мақалада шардың инерция моментін зерттеу үшін виртуалды шындық технологиясын қолдану арқылы бағдарламалық қосымша ұсынылған. Бағдарламалық қосымша эксперимент жүргізу мүмкіндігімен зертханалық жұмыс түрінде орындалған. Мақалада көрнекілік үшін қосымша сценарийлері бар скриншоттар ұсынылған, қосымшаның ^огикасы UML диаграммасы түрінде келтірілген. Әзірлеудің платформасы ретінде WORA (write once, run anywhere) жұмыс принципін жүзеге асыратын Unity 3D кроссплатфорлы ортасы таңдалды. Бұл қағидаттың арқасында бір рет жазылған қосымша дербес компьютерлер, мобильді құрылғылар, аралас шындықтағы шлемдер және басқа да көптеген платформалар үшін жиналу мүмкіндігі бар. Виртуалды шындық құрылғысы ретінде Leap Motion қозғалыс контролмері қолданылды. Қолданба функционалы С\# программалау тілінде жазылған. Графикалық модельдер Substance Painter арқылы жасалды. Әзірленген қосымшаны орта және мамандандырылған мектептердің жоғары сынып оқушылары, жоғары оқу орындарының техникалық мамандықтарының студенттері, сондай-ақ кез келген мүАделі пайдаланушылар қолдана алады.
\end{abstract}

Түйін сөздер: физика, білім беру, виртуалды шындық, виртуалды зертхана, Unity, С\#.

\section{Introduction}

Virtual Reality (VR) [1] is a technology that uses software to reproduce a three-dimensional realistic image of the environment, in which the physical movement of a user is simulated. Using equipment, such as Virtual Reality Glasses, in which headphones, a screen and motion sensors are built in to track user actions, it becomes possible to interact with virtual objects in a virtual environment. Virtual reality technology is widely used in all areas of human activity and, in particular, in education. So, the use of virtual educational resources allows us to solve problems such as the dangers of some experiments, the high cost of laboratory equipment, the inability to simulate some processes in real conditions.

Among the analogues in the field of software development using virtual reality technology for studying physics, the following can be mentioned. In the article [2], the authors talk about the combi- nation of virtual reality and a virtual laboratory for teaching physics to high school students. As part of the Newton project, they created a virtual scene that allows studying the water cycle in nature. It presents virtual reality with a forest, river and mountain landscape. This allows understanding how the water cycle occurs in the wild. To learn the process, the user must follow the instructions that appear on the screen, available in audio format, as well as in the language of the deaf. This approach allows attracting a wider circle of users, as well as students with disabilities. In order to consolidate the information, the student can study this process, but already in a virtual laboratory. The authors [3] conducted a study on the impact of virtual laboratories on student behavior in the study of physics. It involved 42 students, who were divided into groups of 21 people. One of the groups performed tasks using the virtual laboratory; the second was engaged using real physical equipment. Within 5 weeks, the students of both groups conducted 5 experiments. The results 
of the study showed that the use of virtual laboratories has a greater impact on student engagement. The students in the virtual lab also improved their knowledge of the material. Moreover, the most of the students expressed a positive opinion regarding the use of virtual laboratories.

Maroon VR is a virtual laboratory, which is a laboratory room. Two electromagnetic experiments can be carried out in it. Using the HTC Vive helmet, the user can study the behavior and characteristics of electric and magnetic fields [4]. The authors found that users of this approach to the study of the material seemed more interesting, involving, which allowed them to be more focused. In [5], the stages of developing a virtual environment for studying physics are described. Using the application in the lessons allowed improving the methodology of teaching and increasing student' autonomy while working with educational material.

Google Cardboard immerses the user in the world of a virtual laboratory [6]. To get started, the user must put the phone in a helmet. Then, using the interface and the controller connected via Bluetooth, you need to choose the physical movement that the student wants to learn. In [7] the OpenRelativity project was presented. It is implemented using Unity and consists of a library for modifying the shaders built into the game engine. This allows users to demonstrate the world of relativism at an arbitrary speed of light. Learning with the help of such an application, students will be able to familiarize themselves and better understand abstract concepts and topics in the special theory of relativity.

The article by authors from University of Mataram [8] describes the virtual laboratory on electricity complex. Their aim was to create an alternative laboratory set due to limited equipment. The developed laboratory works increased students' engagement and verbal and figural creativity.

Authors of [9] described the virtual laboratory with interactive simulations on biomass for energy generation. It was created for master students of Distributed Renewable Energy. As a result, ethe authors get a feedback from the students about virtual lab as excellent preparatory tool.

Students of $10^{\text {th }}$ grade in [10] used Circuit Construction Kit by PhET simulations. Authors investigated the effect of virtual working set on students and their understanding of circuits.

In [11] the authors wanted to check the efficiency of the virtual laboratory. They created the laboratory work that helps to understand the heat concept and able to increase cognitive aspect and sub-concept of heat among students. As a result, those students who worked with a virtual laboratory showed better achievement of conceptual understanding.

The use of modern teaching methods and new ways of interaction between teachers and students leads to the updating of the educational process. The International Information Technology University is one of the participants of the ERASMUS+ project "Kazakh Universities to Foster Quality Assurance Processes in Technology Enhanced Learning" (KUTEL), the purpose of which is to study the experience of foreign partner universities in the field of ensuring the quality of education when using various technologically enhanced educational solutions learning - TEL). Within the framework of the project, TEL training quality criteria are developed and adapted in relation to domestic curricula and disciplines that use modern technological innovations, such as virtual and augmented reality technologies.

\section{Technological basis}

Among software developers, it is possible to find plugins, which are integrated into game engines, such as Unity3D and Unreal Engine. They make easier to develop software products using virtual reality technology. The main advantages of game engines are cross-platform, usability, a wide range of tools, graphics, sound, technical support. Among the disadvantages are the following: a limited set of tools, difficulty in use, proprietary versions, and inconvenient interface. To develop a software application, the authors identified for themselves such requirements as the availability of information, ease of use and graphics capabilities. Thus, the choice was made in favor of the Unity3D game engine [12]. The logic of the program is implemented using $\mathrm{C} \#$ programming language, which is officially supported by Unity [13].

As a virtual reality device, the Leap Motion controller [14] was used, designed to track the movements of hands and fingers in space and can be used for human-computer interaction. The device includes three infrared LEDs and two cameras, and its principle of tracking is stereoscopy (the reflected light from the LEDs is visible from two different points of view, and the distance from the sensor is calculated accordingly). Thanks to the SDK libraries, you can receive information about tracking both hands in the space above the device at a height of $15-60 \mathrm{~cm}$. The library routines can recognize both hands and transmit information about the location of each bone segment. 


\section{"Determination of ball's inertia moment" virtual laboratory work implementation}

The authors developed a virtual physical laboratory using virtual reality technology to study the moment of inertia of the ball. The work was taken from the Physics book for $10^{\text {th }}$ grade [15]. The developed application allows studying the laws of mechanics using a physical installation consisting of a tripod, an arc-shaped tray, and balls of various sizes. In order to start the interaction with the app the user needs to launch it. Then there will be a choice between tutorial and laboratory work itself. In tutorial the user can get acquainted with the elements of user interface and task completion work order. At the start of the scene with a task, the following screen appears (Figure 1).

Successful execution of the task requires knowledge of the rules and task's order. To do so the user needs to click the button "Description of the task" in the lower left corner of the screen.

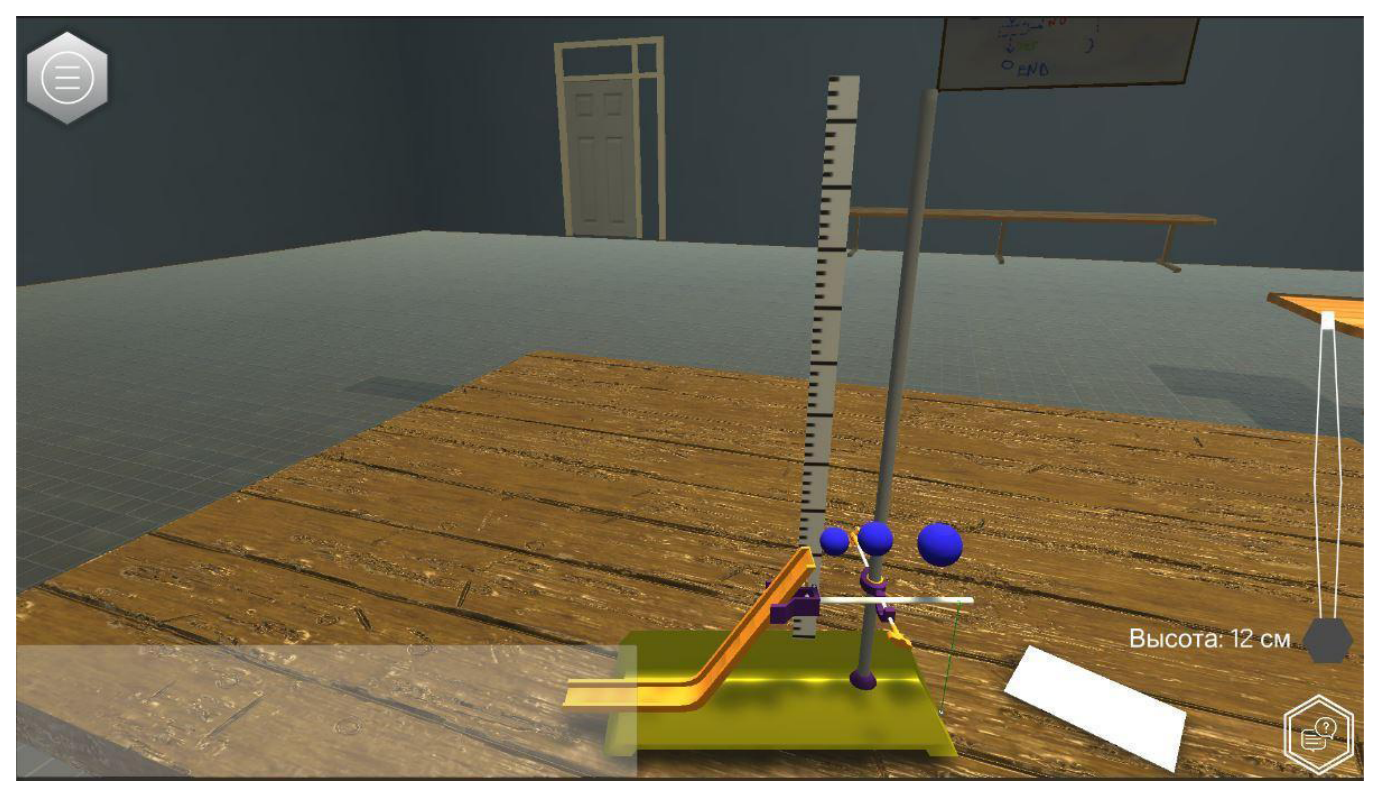

Figure 1 - Installation's common view

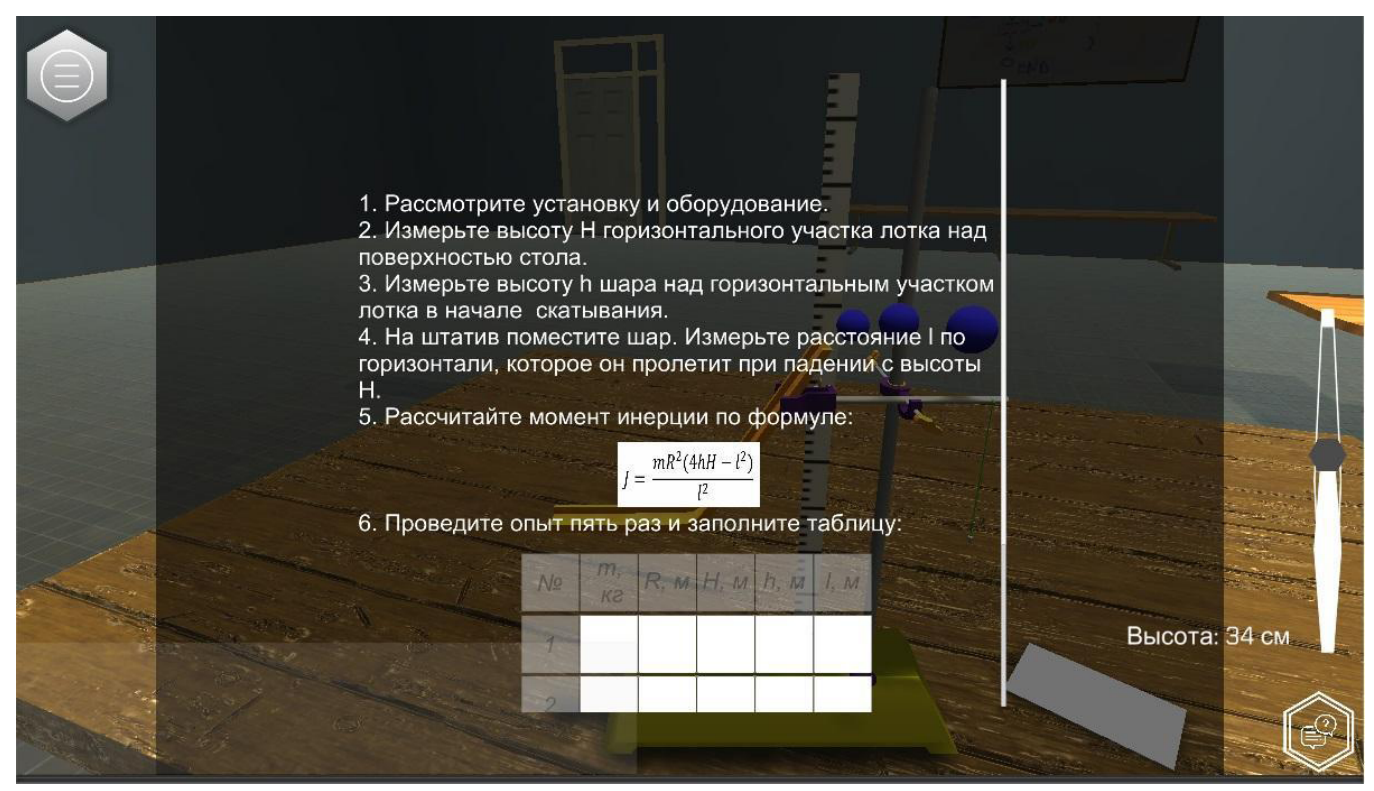

Figure 2 - Description panel with the task 


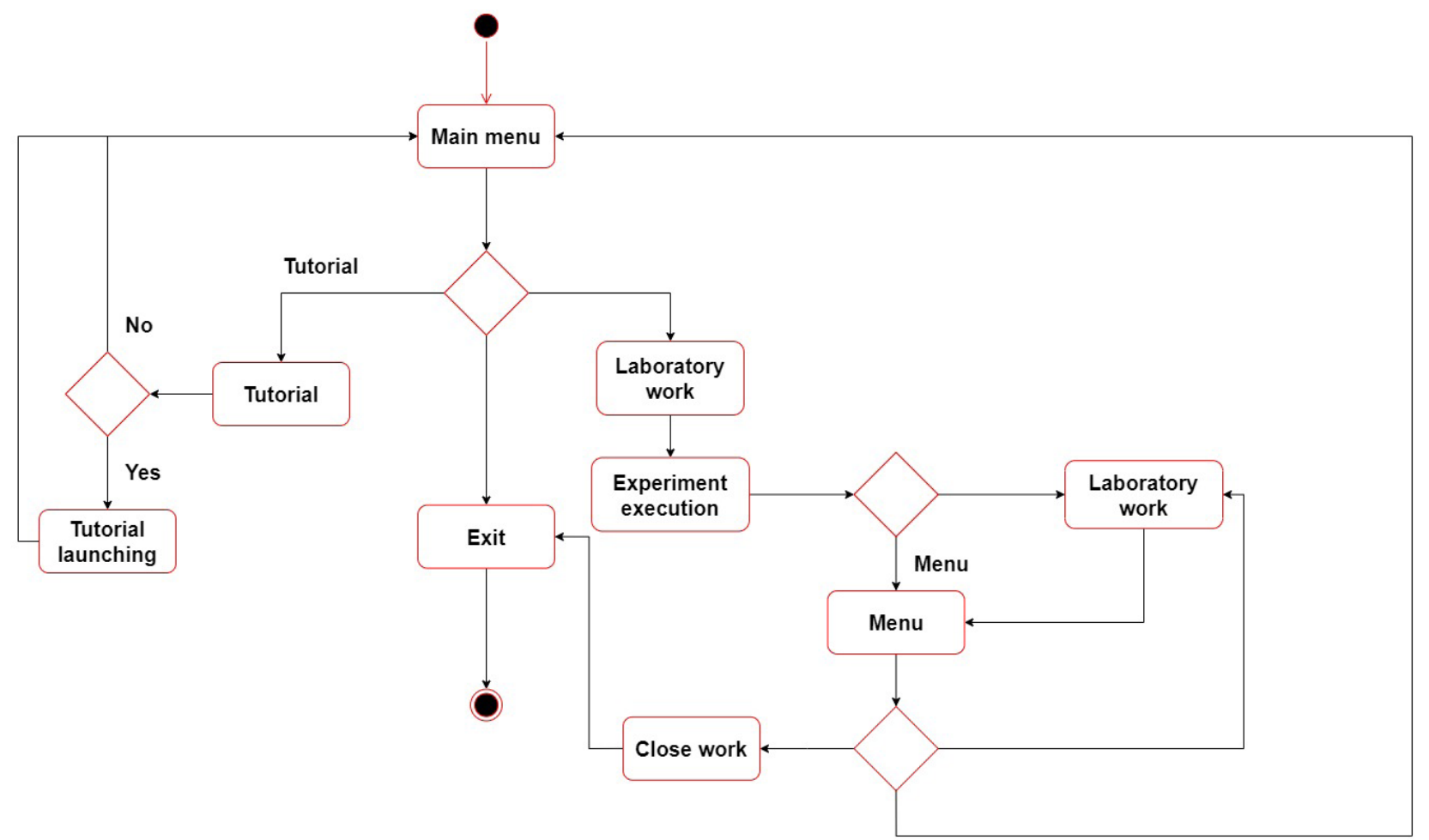

Figure 3 - Activity diagram

According to the Figure 2 the user needs to complete all the steps of the task to finish the laboratory work. The panel with task description also contains the formula that is necessary for calculation of inertia moment. The experiment should be repeated five times and the results must be filled in the table. It will help the user to install dependency of inertia moment value on the changing weight and ball's diameter. In general, the work with the program is described with the activity diagram in the Figure 3.

The formula in the task description panel was obtained using following formulas:kinetic energy of the rotating body and angular velocity. They are given in 1 and 2 equations, where $J$ - moment of inertia, $\omega$ - angular velocity.

$$
\begin{gathered}
W_{\text {rot }}=\frac{J \omega^{2}}{2}, \\
J=\frac{2 W_{\mathrm{gp}}}{\omega^{2}} .
\end{gathered}
$$

To find following equations let's have a look at installation in the Figure 4. It is easy to see that at the point $A$ the ball has potential energy $m g h$. During its falling this energy transforms into kinetic energy of translational motion of the body and kinetic energy of rotational motion. Given that the linear velocity of the center of mass relative to the trench and the linear velocity of the center of mass from the axis of rotation of the points on the surface of the ball relative to the center of mass are equal to each other, we can find the angular velocity. Then, knowing the distance and time of the flight of the ball, we obtain the final formula for finding the moment of inertia of the ball (formula 3).

$$
J=\frac{m R^{2}\left(4 h H-l^{2}\right)}{l^{2}} .
$$

As a result, the student, working with the application and virtual installation, receives the same level of knowledge and experience that can be gained after interacting with the real equipment. Thus, we can conclude that such projects are effective and necessary. 


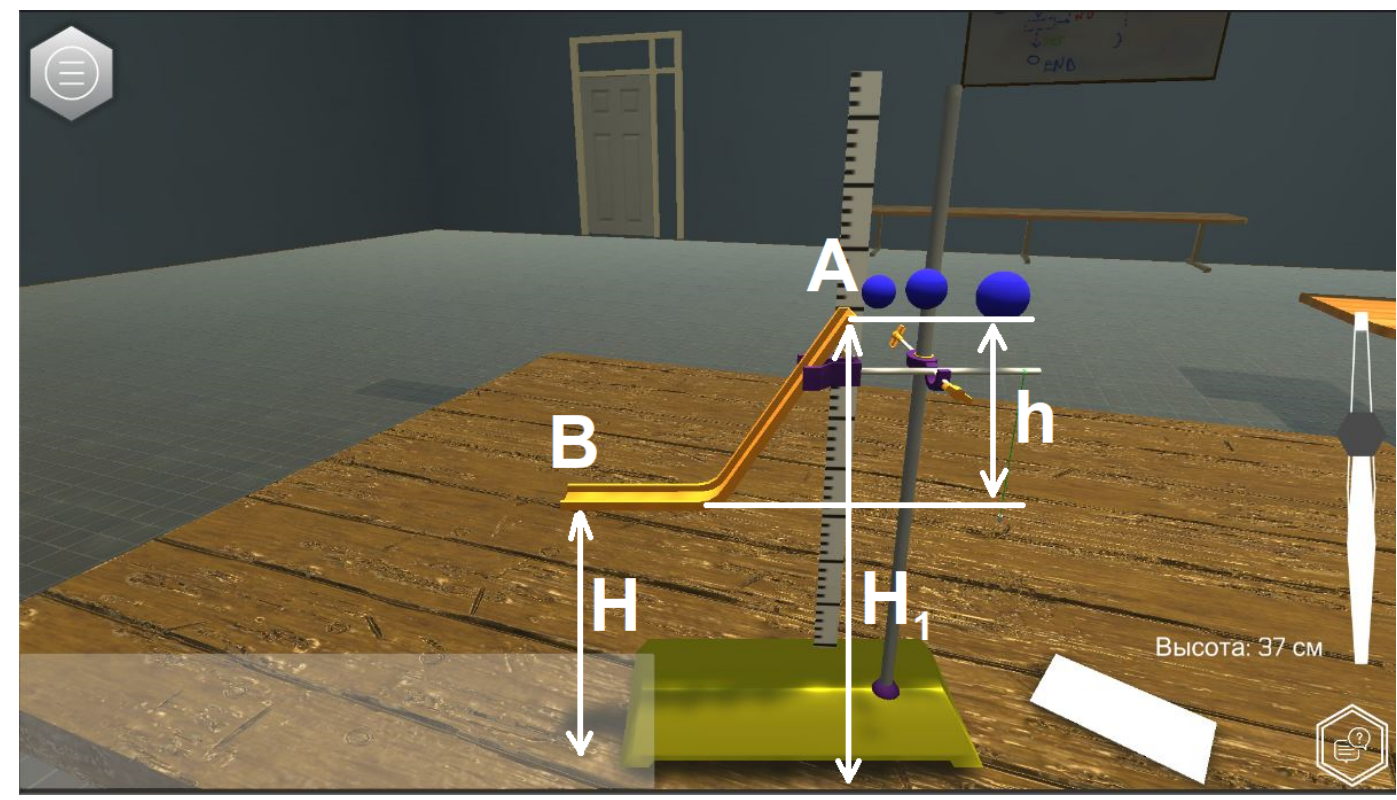

Figure 4 - Lab's installation

\section{Conclusion}

Thus, virtual reality technology takes learning to a new level. Virtual reality has the potential to lead students to new discoveries, motivate, encourage and inspire. Students can participate in the learning environment with a sense of presence, be part of the training environment.

This article presents the experiment that allows studying the moment of inertia of the ball in virtual reality. The developed software product allows interacting with virtual objects using the Leap Motion controller, while remaining simple and convenient to use.
Currently, the application is being introduced into the physics course as an additional source of information in secondary schools. Also, the authors are constantly working to expand the list of laboratory works available for carrying out using the developed application.

\section{Acknowledgmentst}

This work was financially supported by the Ministry of Education and Science of the Republic of Kazakhstan under the grant research funding program for 2018-2020, grant No. AP05135692.

\section{References}

1 Hale, Kelly S., and Kay M. Stanney. Handbook of Virtual Environments: Design, Implementation, and Applications. - Boca Raton: CRC Press, 2017. - 1456 p.

2 Bogusevschi D., Muntean C., Muntean G. M. Teaching and learning physics using 3D virtual learning environment: A case study of combined virtual reality and virtual laboratory in secondary school //Society for Information Technology \& Teacher Education International Conference. - Association for the Advancement of Computing in Education (AACE), 2019. - P.467-474.

3 Yiksoy G., Islek D. The impact of the virtual laboratory on students' attitude in a general physics laboratory //International Journal of Online and Biomedical Engineering (iJOE). - 2017. - Vol. 13(04). - P.20-28.

4 Pirker J., Lesjak I., Guetl C. Maroon VR: A room-scale physics laboratory experience // Advances in Engineering Research. - 2018. - Vol. 149. - P.266-271.

5 Wang H. Application of Virtual Reality Technology in Physics Experiment Teaching //2018 International Conference on Mechanical, Electronic, Control and Automation Engineering (MECAE 2018). - Atlantis Press, 2018.

6 Becerra, D.A.I., Herrera, J.A.Q., Aceituno, R.G.A., Vargas, G.M.P., Zamora, F.G.F., Mango, J.L.H., ... \& Chana, J.W.T. Evaluation of a Gamified 3D Virtual Reality System to Enhance the Understanding of Movement in Physics //CSEDU (1). - 2017. - P.395-401.

7 Sherin, Z.W., Cheu, R., Tan, P., \& Kortemeyer, G. Visualizing relativity: The open relativity project //American Journal of Physics. - 2016. - Vol. 84(5) -P.369-374. 
8 Gunawan, G., Harjono, A., Sahidu, H., \& Herayanti, L. Virtual laboratory of electricity concept to improve prospective physics teachers creativity //Journal Pendidikan Fisika Indonesia. - 2017. - Vol. 13(2). - P.102-111.

9 Redel-Macías, M.D., Pinzi, S., Martínez-Jiménez, M.P., Dorado, G., \& Dorado, M.P. Virtual laboratory on biomass for energy generation //Journal of Cleaner Production. - 2016. - Vol. 112. - P. 3842-3851.

10 Ayoubi Z. The effect of using virtual laboratory on grade 10 students' conceptual understanding and their attitudes towards physics //Journal of Education in Science, Environment and Health. - 2018. - Vol. 4(1). - P.54-68.

11 Hermansyah, H., Gunawan, G., Harjono, A., \& Adawiyah, R Guided inquiry model with virtual labs to improve students' understanding on heat concept //Journal of Physics: Conference Series. - IOP Publishing, 2019. - Vol. 1153(1). - P.012116.

12 Unity 3D, "Company", <https://unity3d.com/company> (Accessed 15 February 2020)

13 Technologies, Unity. "Creation and Using of Scripts." Unity. $<$ https://docs.unity3d.com/ru/current/Manual/CreatingAndUsingScripts.html $>$ (Accessed February 14, 2020)

14 Colgan, A. “How Does the Leap Motion Controller Work?” Leap Motion Blog, 9 August 2014, <http://blog.leapmotion. com/hardware-to-software-how-does-the-leap-motion-controller-work/> (27 February 2020)

15 Krongart B., Kem V., Koishybaev N. Physics: A textbook for 10 grade of the natural-mathematical direction of secondary schools. - Almaty: Mektep. - 2010. - 113 p.

\section{References}

1 Hale, S. Kelly, and Kay M. Stanney, Handbook of Virtual Environments: Design, Implementation, and Applications, (Boca Raton: CRC Press, (2017), 1456 p.

2 D. Bogusevschi, C. Muntean, G.M. Muntean, Society for Information Technology \& Teacher Education International Conference - Association for the Advancement of Computing in Education (AACE), 467-474 (2019).

3 G. Yiksoy, D. Islek, iJOE, 13(04), 20-28 (2017).

4 J. Pirker, I. Lesjak, C. Guetl, Maroon VR:, 17th International Conference on Advanced Learning Technologies (ICALT), 482-484 (2017).

5 H. Wang,Advances in Engineering Research, 149, 266-271 (2018).

6 D.A.I. Becerra, J.A.Q. Herrera, R.G.A. Aceituno, G.M.P. Vargas, F.G.F. Zamora, J.L.H. Mango, J.W.T. Chana, CSEDU, 395-4011 (2017).

7 Z.W. Sherin, R. Cheu, P. Tan, G. Kortemeyer, American J.of Physics, 84(5), 369-374 (2016).

8 G. Gunawan, A. Harjono, H. Sahidu, L. Herayanti, J. Pendidikan Fisika Indonesia,13(2), 102-111 (2017).

9 M.D. Redel-Macías, S. Pinzi, M.P. Martínez-Jiménez, G. Dorado, M.P. Dorado, J. of Cleaner Production,112, 3842-3851 (2016).

10 Z. Ayoubi, J. of Education in Science, Environment and Health, 4(1), 54-68 (2018).

11 H. Hermansyah, G. Gunawan, A. Harjono, R. Adawiyah, J. of Physics: Conference Series, 1153(1), 012116 (2019).

12 Unity 3D, "Company", <https://unity3d.com/company> (Accessed 15 February 2020)

13 Technologies, Unity. "Creation and Using of Scripts." Unity. <https://docs.unity3d.com/ru/current/Manual/CreatingAndUsingScripts.html $>$ (Accessed February 14, 2020)

14 A. Colgan, "How Does the Leap Motion Controller Work?” Leap Motion Blog, 9 August 2014, <http://blog.leapmotion. com/hardware-to-software-how-does-the-leap-motion-controller-work/> (27 February 2020)

15 B. Krongart, V. Kem, N. Koishybaev, Physics: A textbook for 10 grade of the natural-mathematical direction of secondary schools, (Almaty: Mektep, 2010), 113 p. 